resulting from approximately 600 outbred matings when, provided that the frequency of the recessive gene in the population is 1 per cent, there is again a 95 per cent chance of detecting the heterozygous bull.

For the progeny test of young bulls, the Milk Marketing Board carries out 500 inseminations in recorded herds and 500 in non-recorded herds, and these should result in approximately 600 calves being born. Thus if the existing reporting system can be improved, it should be possible to detect the majority of those bulls carrying deleterious recessive genes of importance in the population without resort. ing to sire-daughter matings. This is the procedure which is favoured. It is true that sire-daughter matings will enable the detection of any recessive gene whatever its frequency, but they are difficult to organize in practice, and therefore it is proposed to carry them out only in exceptional cases.

1 Milk Marketing Board, Breeding 10,000,000 Cattle (1959).

${ }^{2}$ Robertson, A., and Rendel, J. M., J. Agric. Sci., 44, 184 (1954).

s McArthur, A. T. G., Proc. Brit. Soc. Anim. Prod. (1954).

Robertson, A., Stewart, A., and Ashton, E.\$D., Proc. Brit. Soc. Anim. Prod. (1956).

${ }^{5}$ Robertson, A., Biometrics., 11, 95 (1955).

- Robertson, A., J. Agric. Sci., 54, 100 (1960).

"Genetic Considerations in Breeding Two Million Cattle to Two Hundred Sires (privately printed, 1959).

${ }^{8}$ Robertson, A., Proc. Brit. Soc. Anim. Prod. (1954).

\title{
OBITUARIES
}

\section{Academician A. F. Joffé}

THE death on October 14, 1960, of A. F. Joffé, one of the pioneers of physies in the U.S.S.R., member of the Russian and many other Academies, is a severe loss for science. Joffé took a most active part in the remarkable and violent development of physics from the dawn of the twentieth century up to the present time. To the last day of his life he never ceased experimenting with his own hands.

Joffé's early work (1907-13) was devoted to experimental substantiation of the quantum theory set out by Einstein in 1905 while investigating the photoelectric effect and photochemical phenomena. The theory provoked at first adverse comments on the part on many eminent physicists (Ladenburg and others). In 1907 Joffé undertook a theoretical treatment of experimental results obtained by Ladenburg and others, and proved convincingly that Einstein's photon theory was not contrary to, but on the contrary justified by, all experimental data, including those of Ladenburg.

Joffé's experiments on the photoelectric effect exhibited in metal dust suspended in the electric field of a condenser provided direct confirmation for Einstein's theory. Joffé showed that under illumination a dust particle loses its electric charge by portions corresponding to the electron charge, the nature of the process being statistical and in keeping with that of the photon theory. The same experiments supported the atomistic theory of electricity. The conditions of Joffe's experiments were somewhat similar to those of R. A. Millikan, who followed the behaviour of oil droplets suspended in an electric field and showed that all fluctuations in droplet charges were multiple integers of the elementary electric charge. The experiments of Millikan and Joffé were conducted simultaneously and independently, and were published in 1911 (Millikan) and 1912 (Joffé).

In 1913 Joffé published his results on the magnetic field of the cathode beam. The occurrence of a magnetic field around the cathode beam was still uncertain at the time. The mere fact was denied by many scientists. Besides providing confirmation for the occurrence of the magnetic field, Joffé succeeded in showing that the field intensity was akin to that of an equivalent current in a metal conductor.

At the beginning of the 'twenties, the advent of quantum mechanics, Joffé reverted to his 1912 experi- ments and found that metal dust particles irradiated by X-rays emitted electrons. These experiments, carried out with Dr. Dobronravov, gave convincing proof that the energy of electrons emitted by dust particles corresponds to that of X-ray quanta.

However, the main trend of Joffe's theoretical and experimental works throughout his life was in the direction of electrical and mechanical properties of dielectrics and semi-conductors. $\mathrm{He}$ may with full justice be considered among the pioneers of the physics of solids. His earliest scientific investigations dealt with elastic and electric properties of quartz. In 1922, while investigating the plastic strain in crystals, Joffé and Kirpicheva discovered that the spots of the Laue diffraction pattern were extended into radial stripes as soon as the elastic limit was exceeded. This was evidence that plastic strain leads to the breaking up of a crystal into differently oriented blocks.

Joffe's disciples extended his investigations to a great variety of crystal bodies, and their work obtained world-wide appreciation. A new trend in the physics of metals arose and was successfully developed.

Another line of experimental investigation pursued by Joffé provided a basis for the theory of crystal strength. Prior to these experiments there was a large discrepancy between the values of crystal strength obtained experimentally and those calculated on the crystal lattice theory. For example, the theoretical limiting value for rocksalt erystals was found to be several hundreds of $\mathrm{kgm} . / \mathrm{cm} .{ }^{2}$, whereas experiment gave a limit of hundreds of gm./ $\mathrm{cm} .^{2}$. Measurements of rocksalt crystals immersed in water and similar experiments carried out with balls of rocksalt cooled in liquid air which were inmersed in boiling water or molten tin showed that under these conditions the limiting strength was close to the theoretical order. The low limit observed before was ascribed to microcracks and other crystal defects.

Another important discovery was made by Joffé when investigating the mechanical properties of crystals. He found that the nature of brittle or plastic destruction of crystals at a given temperature was determined by the relation between the temperature-dependent yield strength and the ultimate tension which is only slightly dependent on temperature. This relation, established later for a number of industrial materials, led to many conclusions of great practical value. 
Of extreme importance were Joffé's investigations on electric properties of dielectrics. Prior to his experiments, all electric phenomena displayed by dielectrics were considered as a sort of agglomeration of anomalies. Joffé found that thin polarization layers were formed at the electrode surfaces during the passage of current through a dielectric crystal. The potential difference of these layers eppeared to be enormous. By allowing for polarization, Joffé showed that the flow of current through a crystal was in strict obedience to Ohm's law. Joffé was the first to discover (in 1916) that the conductivity of the majority of ionic crystals was of an electrolytic nature and due in part to lattice-occluded impurities and in part to thermal dissociation of the lattice.

Joffé and his disciples have conducted a vast amount of work on dielectric breakdown, in particular on breakdown stress as a function of the thickness of the dielectric material. These investigations wore of great importance for the technology of insulating materials.

From 1930 Joffé's interests began to concentrate on semi-conductors. Even then, Joffé was aware of the importance of semi-conductors for engineering problems. Joffé himself and his co-workers were very successful in this field and discovered a number of fundamental facts in the physics of semi-conductors. First of all considerable attention was paid to the working out of techniques for obtaining physical values characteristic of semi-conductors, such as the concentration of carriers, their charge, mobility, etc. Most important was the discovery of the effect of impurities on electric properties of semiconductors. It was shown, moreover, that an excess or a deficiency in some component may exhibit an effect similar to that of an impurity. It appeared, for example, that lead sulphide containing an excess of lead atoms was a conductor of the $n$-type, whereas a sulphur excess would make it $p$-type. Joffé suggested that these facts were due to impurity or excess atoms either creating additional slechron sources or picking up electrons with consequent formation of holes. The conoept of electron-or holo-semi-conductors, now defingd as $n$ - and $p$-type, seems to have originated from Joffé's laboratory.

Towards the end of the 'thirties Joffé, together with his wife, proposed a mechanism of rectification which is now widely accepted. It implies that the barrier-layer in rectifiers is formed at the $p$ - $n$ junction. The flow of current is due to electrons and holes approaching each other and recombining at the junction. When the electrons and holes drift apart, the resistivity of the layer adjacent to the junction is raised and the latter consequently becomes a barrier-layer.

Of the many practical applications of semi-conductors Joffé considered as paramount the utilization of their thermoelectric and photoelectric properties for conversion of heat and light onergy into electric energy. Joffe's theory of thermoelectric genorators (and thermoelectric refrigerators) opened a clear path for physicists and ongineors working in this field. The idea of plasma thermoelectricity, now being developed in many countries, was also set forth by Joffé.

His grest achievements in this domain were emphasized by the emirent American scientist $J$. Bardeen at the International Conference on the Physics of Semi-Conductors in Rochester, 1959. In his inaugural speech Bardeen said: "The first real scientific study of electron mobility, thermal conductivity, and other factors important for thermal elements, and the way they depend on composition was made by Joffé and his co-workers. Results they have obtained clearly demonstrate the virtue of the scientific over the purely empirical approach. . . . . Research on thermoelectric effects and on thermal conduction in semi-conductors has yielded a number of interesting phenomena, involving phonon scattering, phonon drag, and heat transfer by ambipolar diffusion".

A profound and eager concern for all problems of physics and adjacent fields was very characteristic of Joffé as a scientist. A great number of Joffe's ideas, developed later by his disciples, date back to the 'twenties and 'thirties; they laid the foundation for the development in the U.S.S.R. of modern trends of physical science. Joffé acknowledged his authorship only in investigations that were carried. out with his own hands. He was never prone to put his name to papers dealing with investigations that were carried out by his numerous disciples, even though the ideas and guidance were his. This makes his contribution to science, embracing a great variety of physical fields (nuclear physics, chemical physies, the theory of metals, physics of heat, etc), even larger than it would seem at first.

$\mathrm{He}$ created a widely spread school of Soviet physicists dealing with most diverse trends in physics and related scionces. His gift for inspiring his colleagues, especially young ones, with a passionate interest for science was truly remarkable.

Sixteen new institutes were founded under Joffé's sponsorship. In 1918 he created the PhysicoTechnical Institute of Leningrad, which played an exceptionally important part in the development of physics. $\mathrm{He}$ was director of this Institute for more than thirty years, but his activities reached far beyond its scope. He took part in the development of physics all over the country, and his was the idea of a widely spread system of physico-technical institutes and laboratories that would serve as a scientific basis for the growing industry. He contributed largely to the organization of physical institutes in Kharkov, Dnyeporpetrovsk, Tomsk, Sverdlovsk. Groups of able scientists were chosen by him from his staff for work in each of these inatitutes, thus forming the nuclei of future scientific bodies. The Institute of Chemical Physics in Moseow and the Electro-Physical Instituts in Leningrad sprang up from the Loningrad Physico-Technical Institute. The Institute of Physical Agriculture, so far the only one of its kind, was also founded by Joffé. An outstanding Physico-Mechanical Department of an entirely novel type was created by Joffe in the Leningrad Polytechnic Institute. Its programme combines deep penetration into theory with most lively actual practice. Engineers coming from this department possess a profound knowledge of modern physics and are carrying the latest scientific achievements to all fields of industry.

Joffé's remarkable personality, his immense seientific prestige and wide erudition, his unquenchable passionate love for science, his gift for inspiring his disciples, his rare simplicity and affability won him respect and affection among the widest circles of scientists and engineers of the Soviet Union, deep friendship on the part of his disciples, including the present writers. The strongest bonds of friendship tied him with eminent scientists of many countries. It will be hard for all who know him to accept the fact that he is no more, that the hearty man who 
seemed unaware of age, so full of the joy of life and far-reaching projects, has gone, that the tireless, wonderful intellect has ceased to exist.

\section{N. N. SEMENov}

V. N. Kondratiev

\section{Prof. C. W. Dannatt}

Prof. Cecil William Dannatt, who died at his home in Blackheath on April 9, was born on August 2, 1892. He was educated at Colfe's Grammar School and the Royal School of Mines, where he graduated in metallurgy in July 1914. In August of the same year he enlisted in the Queen's Westminster Rifles. He received a commission in 1915 and served in France, Saloniks and Palestine. On being demobilized in 1918, he joined the Ministry of the Interior, Cairo, as assistant director of the Technical Section of the Public Security Department. After two years of very varied experience in this post, he went to Trinidad as geologist to an oil company, but in 1923 he returned to the Royal School of Mines, to work as a research student in the Metallurgy Department. A few months later he joined the teaching staff of the Department, and the work was so much to his liking, and he so well fitted for it, that he remained on the staff for thirty-four years, first as demonstrator, then lecturer, reader, acting director and finally, from 1945 until his retirement in 1957, professor and head of the Metallurgy Department.

Throughout his long connexion with the Royal School of Mines and Imperial College, and particularly after his appointment as professor, he devoted him. self to the advancement of the Department, and the training and education of his students, in every one of whom he took a personal and sincere interest. Under his leadership, the Department added continuously to its reputation as a centre of learning and research, and when he handed over to his successor in 1957 he was able to do so in the knowledge that its standing had never been higher. Although his interests and knowledge extended to all branches of metallurgy, and he was a vigorous opponent of specialization within his Department, his greatest interest was in fact in the scientific and technological aspects of the extraction of metals from their ores, and the achievement that afforded him more gratifica. tion than any other was the formation of the Nuffield Research Group in Extraction Metallurgy. He was largely responsible for the establishment of this group in his Department in 1950, since when, with his active support, it has developed into the leading academic research school devoted to the study of metallurgical processes at high temperatures.

Prof. Dannatt had a charming and gracious personality, and he was an unsparing worker. $\mathrm{He}$ was always anxious to help, and always reluctant to refuse any request for advice or information, or demand for his services. Scientific societies, professional institutions, educational and examining bodies, and Government, college and university committees made many such demands not just on account of his position but also because his wide knowledge, alert mind and ability to express himself lucidly and concisely were powerful assets in committee work. He particularly valued his long association with the Institution of Mining and Metallurgy, of which he was president during 1956-57, the Institution of Metallurgists, of which he was vice-president during 1953-57, the Sir John Cass College and Woolwich Polytechnic, as member of their governing bodies, and the City and Guilds of London Institute, as member of the General Advisory Committee and Moderating Committee for Metallurgical Subjects.

Shortly after his retirement, the title of professor emeritus of metallurgy was conferred on him by the University of London, and in 1960 he became a Fellow of the Imperial College. Although incapacitated by a prolonged and severe illness, he retained his interest in metallurgy to the end. $\mathrm{He}$ is survived by his widow and daughter.

M. S. Fisher

\section{Prof. J. Bordet, For.Mem.R.S.}

Jules BoRdet, who died at his home in Ixelles in Belgium on April 6, was a pioneer in the science of microbiology and the allied one of immunology. The last twenty-five years of his life-he died at the age of ninety - were spent in retirement and he had used the early years of this period of leisure to prepare a second edition of his excellent text-book, Traité de l'Immunité dans les Maladies Infectieuses, which appeared in 1939. But in the closing years of the past century and the first thirty years of this one, Bordet's brilliant mind and experimental skill led to discoveries of fundamental importance and a flow of scientific papers which established for him an indisputable claim to fame.

Bordet was born in Soignies, Belgium, on June 13, 1870. Electing to enter the profession of medicine, he studied at the University of Brussels, graduating M.D. in 1892. Choosing a laboratory career, he went to the Pasteur Institute, Paris, in 1894, and worked there for seven years, being recalled in 1901 to become first director of the newly founded Pasteur Institute, Brussels. Six years later he was appointed to the chair of bacteriology in the University of Brussels, holding this post until his retirement in 1935 .

Bordet's inquiring mind led to his study of many aspects of microbiology, among others, anaerobiosis, bacterial agglutination, the pleuropneumonia group of micro-organisms and the bacteriophages, on all of which he made valuable original observations. It was, however, his investigations into the ætiology of whooping-cough and his elaboration of the complement-fixation test, in both of which he had the assistance of his colleague, Gengou, that stood out above the rest. It was he and Gengou who, in 1906, discovered the causal agent of whooping-coughHaemophilus pertussis - a discovery which has made possible the specific prophylaxis of this disease; and it was at the end of the last century, in 1895 to be precise, that he published his first paper on bacteriolysis, showing that lysis of a bacterium by an immune serum was the work of two serum components, specific heat-stable antibody and non-specific heatlabile complement. It was from this observation, of course, that the complement-fixation test emerged (1901), with its wide application in the diagnosis of disease.

Recognition of the value of these researches brought Bordet many honours. In 1911 he was given the Prix de la Ville, Paris, and two years later the Swedish Medical Society awarded him the Hansen Prize and the Pasteur Medal. He was made a foreign member of the Royal Society in 1916, and in 1919 he was given the Nobel Prize for medicine and physiology; the University of Cambridge conferred on him the honorary degree of M.D. Bordet was married and had three children, a son and two daughters. 